\title{
Ribosome Dysfunction Is an Early Event in Alzheimer's Disease
}

\author{
Qunxing Ding, ${ }^{1}$ William R. Markesbery, ${ }^{2,3}$ Qinghua Chen, ${ }^{3}$ Feng Li, ${ }^{3}$ and Jeffrey N. Keller ${ }^{1,3}$ \\ Departments of ${ }^{1}$ Anatomy and Neurobiology and ${ }^{2}$ Pathology and Neurology and ${ }^{3}$ Sanders-Brown Center on Aging, University of Kentucky, Lexington, \\ Kentucky 40536-0230
}

\begin{abstract}
Alzheimer's disease $(\mathrm{AD})$ is a progressive and devastating disorder that is often preceded by mild cognitive impairment (MCI). In the present study, we report that in multiple cortical areas of MCI and AD subjects, there is a significant impairment in ribosome function that is not observed in the cerebellum of the same subjects. The impairment in ribosome function is associated with a decreased rate and capacity for protein synthesis, decreased ribosomal RNA and tRNA levels, and increased RNA oxidation. No alteration in the level of initiation factors was observed in the brain regions exhibiting impairments in protein synthesis. Together, these data indicate for the first time that impairments in protein synthesis may be one of the earliest neurochemical alterations in $\mathrm{AD}$ and directly demonstrate that the polyribosome complex is adversely affected early in the development of AD. These data have important implications for AD studies involving proteomics and studies analyzing proteolysis in $\mathrm{AD}$, indicate that oxidative damage may contribute to decreased protein synthesis, and suggest a role for alterations in protein synthesis as a novel contributor to the onset and development of AD.
\end{abstract}

Key words: Alzheimer's disease; mild cognitive impairment; oxidative stress; protein synthesis; ribosome; tRNA; rRNA

\section{Introduction}

Alzheimer's disease $(\mathrm{AD})$ is a progressive and devastating agerelated disorder that is the primary cause of dementia in subjects over the age of 65 years (Seshadri et al., 1997; DeKosky, 2003). A number of individuals in the elderly population develop a condition known as mild cognitive impairment (MCI), with MCI subjects developing $\mathrm{AD}$ at a significantly higher rate than the at-large elderly population (Flicker et al., 1991; Morris et al., 2001; Luis et al., 2003). Several studies suggest that MCI may be the earliest stage in AD (Flicker et al., 1991; Morris et al., 2001; Luis et al., 2003), making MCI potentially useful for identifying and understanding the earliest biochemical alterations that occur in $\mathrm{AD}$.

To maintain cellular homeostasis, all cells must continually synthesize new proteins. Ribosomes (polyribosomes) are specialized complexes composed of nucleic acids and proteins that are responsible for mediating all protein synthesis. Specialized nucleic acids, rRNA and tRNA molecules, are essential for ribosomes to translate mRNA into proteins (Yang, 1996; FromontRacine et al., 2003; Han et al., 2003; Tschochner and Hurt, 2003; Granneman and Baserga, 2004). A large group of proteins, known as initiation factors, also play an important regulatory role in controlling the rate and specificity of ribosome function. $\mathrm{Nu}-$ merous studies have provided indirect evidence that suggests al-

Received March 20, 2005; revised Aug. 11, 2005; accepted Aug. 13, 2005.

This work was supported by National Institutes of Health Grants AG018437, 5P01-AG005119, and 5P50-AG05114 and by a grant from the Abercrombie Foundation. We thank Dr. Harry Levine for helpful discussion of the studies reported in this manuscript and Sonya Anderson for help with obtaining tissue. We thank the participants of the Biologically Resilient Adults in Neurological Studies study, without whom none of this work could be possible.

Correspondence should be addressed to Dr. Jeffrey N. Keller, 205 Sanders-Brown Center on Aging, 800 South Limestone, University of Kentucky, Lexington, KY 40536-0230. E-mail: Jnkell0@pop.uky.edu.

DOI:10.1523/JNEUROSCI.3040-05.2005

Copyright $\odot 2005$ Society for Neuroscience $\quad$ 0270-6474/05/259171-05\$15.00/0 terations in protein synthesis may occur in $\mathrm{AD}$ (Sajdel-Sulkowska and Marotta, 1984; Langstrom et al., 1989; Chang et al., 2002; Ferrer, 2002; An et al., 2003; Li et al., 2004). In the present study, we sought to clarify whether alterations in protein synthesis occur in AD. Our data demonstrate for the first time that impairments in protein synthesis occur in the earliest stages of $\mathrm{AD}$, occurring in affected cortical regions but not the cerebellum, with impairments in proteins synthesis apparently mediated by both alterations in ribosomal nucleic acids as well as the polyribosomal complex itself. These data have important implications for studies involving the analysis of proteomics and proteolysis in $\mathrm{AD}$ and suggest a novel role for alterations in protein synthesis as a potential mediator of $\mathrm{AD}$ pathogenesis.

\section{Materials and Methods}

Human subjects. The diagnosis of MCI, AD, and normal cognitive function was defined by clinical-neuropathological consensus conference. A total of 10 control [six male (M)/four female (F)], eight MCI (three $\mathrm{M}$ /five $\mathrm{F}$ ), and eight end-stage $\mathrm{AD}$ (three $\mathrm{M} /$ five $\mathrm{F}$ ) subjects were used for all studies. For control, MCI, and AD, there were no significant differences in age ( $82 \pm 7,89 \pm 4,81 \pm 8$ years), brain weight (1250 \pm 143 , $1124 \pm 98,1133 \pm 170 \mathrm{~g})$, or postmortem interval $(3 \pm 0.9,3 \pm 0.9$, $3.1 \pm 0.5 \mathrm{~h})$. Significant differences in Mini-Mental State Evaluation (control, $29 \pm 1 ; \mathrm{MCI}, 26 \pm 3 ; \mathrm{AD}, 6 \pm 7$ ) and Braak stage (control, $1.3 \pm$ 0.5 ; MCI, $3.2 \pm 0.5 ; \mathrm{AD}, 5.7 \pm 0.4)$ were observed in $\mathrm{MCI}$ and $\mathrm{AD}$ subjects, compared with control. The time between death and the time subjects were last tested in the clinic was $10.6 \pm 9$ months for control, $11.5 \pm 4$ months for MCI, and $23 \pm 16$ months for AD subjects. All patients, including those in the Biologically Resilient Adults in Neurological Studies program, were studied longitudinally as part of the University of Kentucky Alzheimer's Disease Research Center. The clinical criteria used for the diagnosis of amnestic MCI were as described previously (Petersen et al., 1997, 1999).

Neuropathology. All subjects were evaluated in the same way at autopsy. Diffuse plaques, neuritic plaques, and neurofibrillary tangles were 
assessed in the five most involved areas of four neocortical sections, hippocampal CA1 and subiculum, amygdale, and entorhinal cortex. For this study, these lesions were assessed in the middle temporal gyrus using the modified Bielschowsky stain. Braak staging was determined using the Gallyas and Bielschowsky-stained sections (Braak and Braak, 1991). Within the inferior parietal lobule (IP) of control, MCI, and AD used in the present study, we quantified the average number of diffuse plaques $(8 \pm 5,32 \pm 8,50 \pm 11)$, neuritic plaques $(6 \pm 3,12 \pm 2,28 \pm 5)$, and neurofibrillary tangles $(0.1 \pm 0.1,2 \pm 1,14 \pm 1)$ in a $1 \mathrm{~mm}$ field. All methods and criteria for neuropathology were identical to those published previously (Riley et al., 2002; Keller et al., 2005).

Purification and analysis of polyribosomes. Polyribosomes were purified and analyzed for their ability to translate proteins as described previously (Cosgrove and Rapoport, 1986; Aloni et al., 1992). Briefly, frozen brain specimens from the indicated brain region were placed in buffer A [containing the following (in mM): 320 sucrose, 50 HEPES, 140 potassium acetate, 4 magnesium acetate, 2.5 dithiotheritol, $\mathrm{pH} 7.5$ ], using a 2.5 vol of buffer A. The tissue was homogenized on ice using a glass-Teflon homogenizer. The resulting homogenate was centrifuged at $11,220 \times g$ for $10 \mathrm{~min}$ at $4^{\circ} \mathrm{C}$. The resulting supernatant was used for in vitro protein synthesis assays. Polyribosomes $(100 \mu \mathrm{g})$ were placed in buffer B $(10 \mathrm{~mm}$ potassium acetate, $0.1 \mathrm{~mm}$ magnesium acetate, $0.5 \mu \mathrm{M} \mathrm{ATP,} 0.5 \mu \mathrm{M}$ GTP, $0.5 \mu \mathrm{M}$ creatine phosphate) containing $50 \mu \mathrm{g} / \mathrm{ml}$ creatine phosphokinase. The total volume of the reaction was brought to $99 \mu \mathrm{l}$, and $1 \mu \mathrm{l}$ of $\mathrm{S}^{35}$ methionine $(10 \mu \mathrm{Ci})$ was added. After increasing periods of incubation $(0,5,10 \mathrm{~min})$, the reaction was stopped by adding $150 \mu \mathrm{l}$ of $1 \mathrm{M}$ potassium hydroxide and $2 \mathrm{mg} / \mathrm{ml}$ methionine. After a $10 \mathrm{~min}$ incubation at $37^{\circ} \mathrm{C}$, the proteins were precipitated overnight at $4^{\circ} \mathrm{C}$ using $250 \mu \mathrm{l}$ of ice-cold $25 \%$ trichloroacetic acid containing $2 \mathrm{mg} / \mathrm{ml}$ methionine. The solution was then centrifuged at $13,100 \times g$ for $10 \mathrm{~min}$ at $4^{\circ} \mathrm{C}$, washed twice with $10 \% \mathrm{TCA}$, and resulting incorporation of $\mathrm{S}^{35}$ methionine into protein measured using a scintillation counter.

Real-time reverse transcription- $P C R$. Total RNA was isolated from the inferior parietal lobule as described previously by our laboratory (Ding et al., 2002). The primers for individual rRNA or tRNA species are provided below. The conditions for real-time PCR were as follows: $50^{\circ} \mathrm{C}$ for $2 \mathrm{~min}$, $95^{\circ} \mathrm{C}$ for $10 \mathrm{~min}$, and $30 \mathrm{cycles}$ of amplification $\left(95^{\circ} \mathrm{C}\right.$ for $15 \mathrm{~s}, 55^{\circ} \mathrm{C}$ for $30 \mathrm{~s}$, and $72^{\circ} \mathrm{C}$ for $40 \mathrm{~s}$ ). Primer sequences were selected using a commercially available system (Primer Express; Applied Biosystems, Foster City, $\mathrm{CA})$. For each reaction, a single prominent band of the correct size was generated, with all data obtained within the linear range of amplification for each gene product. Data analysis was conducted using ABI Prism 7000 SDS software (Applied Biosystems, Warrington, UK).

Western blot assay of translation initiation factors. Whole-tissue lysates were generated from the inferior parietal lobule of each patient, with 50 $\mu \mathrm{g}$ of total proteins loaded for Western blot analysis as described previously by our laboratory (Ding et al., 2002). Antibodies against FK506binding protein-rapamycin-associated protein (FRAP), phosphorylated p70 S6 kinase, phosphorylated eukaryotic initiation factor 2 (eIF2 $\alpha$ ), and phosphorylated double-stranded RNA-activated protein kinase (PKR) were purchased from Santa Cruz Biotechnology(Santa Cruz, CA) and Cell Signaling Technology (Beverly, MA). The resulting bands were digitalized and quantified using NIH ImageJ.

Analysis of 8-hydroxyguanosine immunoreactivity. The amount of RNA oxidation was quantified by analysis of 8-hydroxyguanosine (8-OHG) levels in the total RNA pool (Ding et al., 2004). The RNA (15 $\mu \mathrm{g})$ was separated using denatured agarose gel and transferred to membrane. Antibody against 8-OHG (QED Biosciences, San Diego, CA) was used to detect the oxidized nucleic acids. Total RNA isolation and transferring was described previously by our laboratory (Ding et al., 2002). The data were digitalized and analyzed by Image J (NIH Image software).

Statistical analysis. For determinations of statistical significance between control, MCI, and early AD, a Student's $t$ test or a one-way ANOVA with post hoc Tukey's studentized range test for multiple comparisons was used. In this analysis, $p<0.05$ was considered statistically significant.

\section{Results}

\section{Ribosomal alterations in $\mathrm{MCI}$ and $\mathrm{AD}$}

Polyribosome complexes from control, MCI, and AD subjects were isolated from IP, superior middle temporal gyri (SMTG), and cerebellum. The polyribosome content present in $1 \mathrm{mg}$ of brain tissue from the different brain regions was quantified, with no significant alterations in polyribosome content observed between control, MCI, and AD subjects (Fig. 1A). We then examined the ability of an equal amount of polyribosome complexes $(100 \mu \mathrm{g})$ from the different brain regions to synthesize proteins. A significant decline in the rate of protein synthesis was observed in the SMTG and IP of both MCI and AD subjects (Fig. $1 B$ ), compared with control subjects. We then quantified the total protein synthesis capability for each brain region by multiplying the specific activity of polyribosomes by the amount of polyribosomes present in $1 \mathrm{mg}$ of brain tissue. When the total protein synthesis capability was quantified, a dramatic inhibition of protein synthesis capability was observed in the SMTG and IP of both MCI and $\mathrm{AD}$ (Fig. 1C). No significant difference in the total protein synthesis capability was observed in the cerebellum of control, MCI, and AD subjects (Fig. 1C).

\section{Altered rRNA and tRNA levels observed in MCI and AD}

We next sought to determine whether the expression or processing of ribosomal associated nucleic acids (rRNA, tRNA) was altered in MCI and AD. The maturation of rRNA is a highly regulated, progressive, and stepwise process that yields multiple products (Fromont-Racine et al., 2003; Granneman and Baserga, 2004). Within the cerebellum, there was no significant difference in the levels of individual rRNA species in either MCI or AD subjects (Fig. 2A). In contrast, within the IP, the AD subjects exhibited significantly lower levels of 5.8S and 5S rRNA compared with control subjects (Fig. $2 B$ ). Subjects with MCI exhibited significantly lower levels of $5 S$ precursor and $5 S$ rRNA compared with control subjects (Fig. $2 B$ ). Within the cerebellum, an individual tRNA species ( $\mathrm{tRNA}^{\mathrm{val}}$ ) was significantly lower in MCI subjects (Fig. 2C). No other significant alteration in tRNA species was observed in the cerebellum of control, MCI, and AD subjects (Fig. $2 C$ ). In the IP, there was a significant decrease in tRNA $^{\text {asn }}$ in AD subjects (Fig. 2D), with MCI subjects exhibiting a decrease in tRNA ${ }^{\mathrm{val}}$ and $\mathrm{tRNA}^{\mathrm{cys}}$ within the IP (Fig. $2 D$ ). No other significant alterations in tRNA species were observed in the IP of control, MCI, and AD subjects (Fig. 2D). Results in the SMTG were similar to those observed in the IP (data not shown).

\section{Analysis of initiation factor pathways}

Because decreased protein synthesis may be mediated by alterations in the expression of initiation factors, we next sought to elucidate whether alterations in several established regulators of initiation factors was evident in MCI and early AD brain. Analysis of several such factors (FRAP, phosphorylated p70S6 kinase, phosphorylated PKR, phosphorylated eIF2 $\alpha$ ) were quantified by Western blot in the cerebellum (Fig. 2 E) and IP (Fig. 2 F). Within the cerebellum, there was a significant increase in FRAP, phosphorylated p70S6 kinase, and phosphorylated eIF2 $\alpha$ in AD subjects (Fig. 2E). Within the IP, no significant difference in the expression of any of these key regulators of initiation factor activity was observed (Fig. $2 F$ ). No significant alteration in the expression of these initiation factors was observed within the SMTG, with the exception that a significant decrease in phosphorylated eIF2 $\alpha$ was observed in AD subjects (data not shown). 

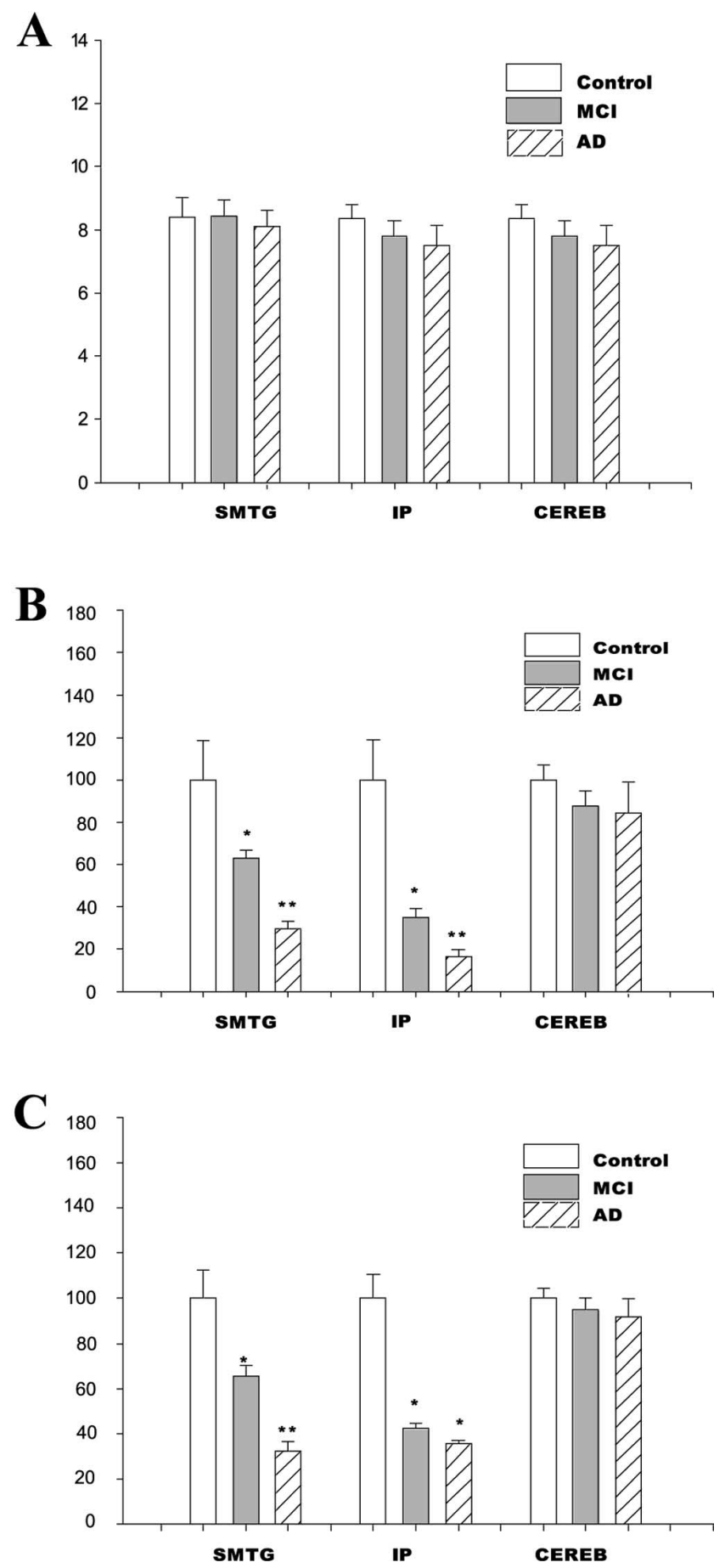

Figure 1. Ribosome function is altered in $\mathrm{MCl}$ and $\mathrm{AD}$. $\boldsymbol{A}$, The polyribosome content was measured in the SMTG, IP, and cerebellum. Analysis was conducted using $1 \mathrm{mg}$ of brain tissue from each brain region in control, $\mathrm{MCl}$, and $\mathrm{AD}$ subjects. $\boldsymbol{B}$, The rate of protein synthesis (specific activity) was measured in each of the brain regions used for polysome content, using $100 \mu \mathrm{g}$ of polysome. The rates of protein synthesis were calculated as the number of counts in precipitate per minute and then expressed as percentage control. $C$, The total protein synthesis capability for $1 \mathrm{mg}$ of brain tissue (polyribosome-specific activity $\times$ amount of polyribosome in $1 \mathrm{mg}$ of tissue) was calculated for each brain region. The data are presented as the mean and SEM. ${ }^{*} p<$ 0.03 compared with control; ${ }^{* *} p<0.05$ compared with either control or MCI. CEREB, Cerebellum.

\section{Elevation in RNA oxidation evident in MCI and early AD}

In our last set of experimentation, we sought to elucidate whether there was any evidence for elevations in RNA oxidation, in particular rRNA oxidation, occurring in the same areas of the brain that exhibited impairments in protein synthesis. Analysis of 8-OHG levels was conducted using total RNA purified from either the cerebellum or IP, which was analyzed using a Northern immunoblot approach (Ding et al., 2004). These studies revealed that there was no significant difference in the amount of 8-OHG present within the cerebellum of control, MCI, or AD subjects (Fig. $2 G$ ). In contrast, significantly higher levels of 8 -OHG were present in the IP of MCI and AD subjects (Fig. 2G), compared with control subjects. Interestingly, in IP samples, prominent levels of RNA oxidation were evident in the region of the membrane that corresponds to $28 \mathrm{~S}$ rRNA (Fig. 2G). Analysis of 8-OHG in the SMTG revealed increases similar to those observed in the IP (data not shown).

\section{Discussion}

In the present study, we demonstrate for the first time that an impairment in protein synthesis occurs early in $\mathrm{AD}$, evident in the brain of both $\mathrm{MCI}$ and $\mathrm{AD}$ subjects. The impairment in protein synthesis (decrease in specific activity of polyribosomes) was observed in areas of the brain involved in regulating cognition (IP and SMTG) but was not observed in the cerebellum. Based on the neuropathology observed in our cohort of MCI subjects, it does not appear that declines in protein synthesis are regulated by either the severity of neurofibrillary tangles or neuritic plaque formation, although both of these factors likely contribute to the declines in protein synthesis observed in $\mathrm{AD}$ brain. Although we cannot rule out the possibility that impairments in brain metabolism contribute to the declines in protein synthesis observed in the present study, it does not appear to be a principle factor for decreased protein synthesis. This is based on the fact that the impairment of protein synthesis was similar in MCI and AD subjects, although it is known that $\mathrm{AD}$ subjects have a more pronounced decrease in brain metabolic activity, compared with MCI or control subjects.

Several factors appear to contribute to the decline in protein synthesis observed in MCI and AD subjects. For example, in the present study, we observed significant alterations in individual tRNA species, demonstrate evidence for altered levels of rRNA processing, and observed evidence for increased rRNA oxidation in the brain of $\mathrm{MCI}$ and $\mathrm{AD}$ subjects. It is likely that each of these factors not only contributes to the decrease in polyribosome activity, but it is also likely that each of these events is related. For example, the oxidation of tRNA and rRNA species is likely to affect both their stability and function, whereas changes in tRNA and rRNA expression likely occur as a compensatory mechanism to allow the cells to successfully respond to environmental and genetic stressors, including oxidative stressors.

In our study, decreased levels of tRNA ${ }^{\text {val }}$ were observed in both the cerebellum and IP of MCI subjects, whereas decreased levels of tRNA ${ }^{\text {asn }}$ were only observed within the IP of AD subjects. When placed in conjunction with our analysis of protein synthesis, these data indicate that decreases in individual tRNAs do not appear to be sufficient to impair protein synthesis and suggest that the ability of individual tRNAs to influence the rate of protein synthesis may be cell-type and brain-region specific. It will be important in future studies to determine the mechanisms responsible for altering tRNA levels in the brain and identifying the contribution of altered tRNA expression to the overall rates of protein synthesis during physiological and pathological conditions.

In the present study, we found no evidence for alterations in initiation factors contributing to declines in protein synthesis. Previous studies have reported that elevations in phosphorylated 
PKR (Peel and Bredesen, 2003; Onuki et al., 2004), phosphorylated eIF $2 \alpha$ (Chang et al., 2002), and phosphorylated p70S6 kinase (An et al., 2003) occur in brain regions that are affected in $\mathrm{AD}$. It is important to point out that the majority of these previous studies used immunohistochemical analysis to examine changes in protein expression and focused on neuronal immunostaining, whereas the present study used Western blot analysis for quantification. In studies in which Western blot analysis was conducted, studies only found differences in the nuclear fraction (Onuki et al., 2004) and used brain tissue with significantly higher postmortem interval (An et al., 2003; Onuki et al., 2004). Increases in FRAP, phosphorylated p70S6 kinase, and phosphorylated $\operatorname{eIF} 2 \alpha$ were observed in the cerebellum of AD subjects in the present study. Such data raise the possibility that elevations in these proteins may play a direct role in the maintenance of protein synthesis within the cerebellum of AD subjects. Previous studies have suggested that elevations in initiation factors, and their regulators, play a contributory role to $\mathrm{AD}$ pathogenesis (An et al., 2003; Onuki et al., 2004). In future studies, it will therefore be critical to elucidate the contribution of elevated, as well as impaired, levels of initiation factor activation to $\mathrm{AD}$ pathogenesis.

The findings in this study build on the previous studies that demonstrated evidence for alterations in protein synthesis occurring within the late-stage $\mathrm{AD}$ brain (Sajdel-Sulkowska and Marotta 1984; Langstrom et al., 1989) and studies demonstrating evidence for increased oxidative damage to RNA occurring in latestage AD (Nunomura et al., 1999; Honda et al., 2005). In particular, our studies demonstrate that in the earliest forms of $\mathrm{AD}$ pathogenesis alterations in the level of individual rRNA and tRNA species, as well as the oxidation of rRNA species, are associated with a potentially important pathological impairment in protein synthesis, which selectively occurs within the brain regions involved in regulating cognition.

We hypothesize that impairments in protein synthesis, mediated in part by oxidative stress, contribute to impaired neuronal function and the development of neuropathology in AD. For example, impaired protein synthesis could compromise the ability of cells to generate the various factors that are needed to regulate homeostasis. Alternatively, the observed alterations in tRNA may promote the generation of translational errors or cause an early termination of translation (Han et al., 2003). In either case, potentially deleterious protein species could be generated and contribute to both protein aggregation and neurotoxicity (Wang et al., 2004). Studies in yeast have demonstrated that the toxicity of protein synthe-

\section{Cereb}
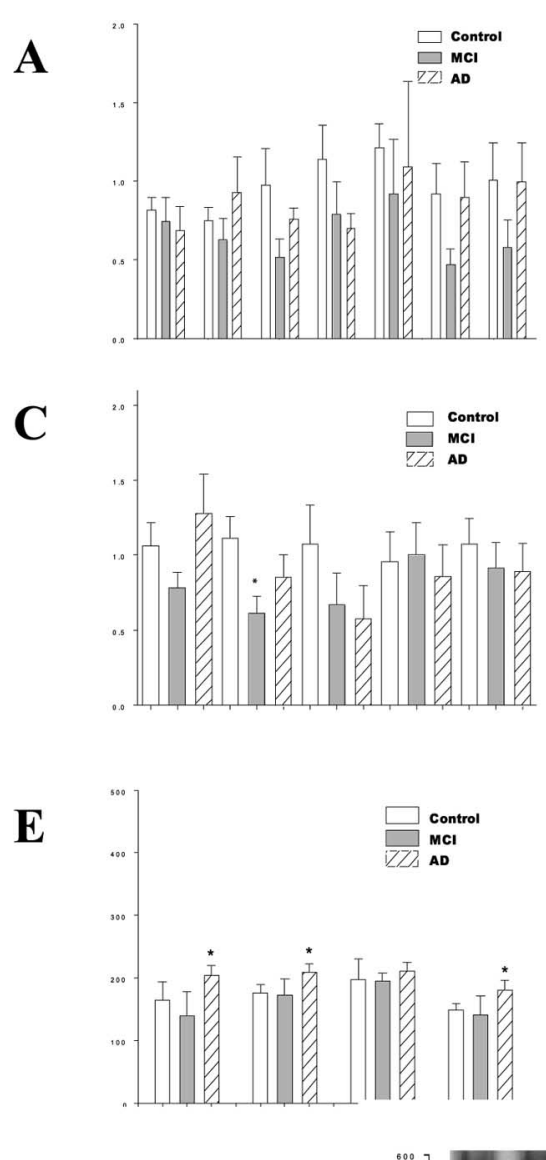

B

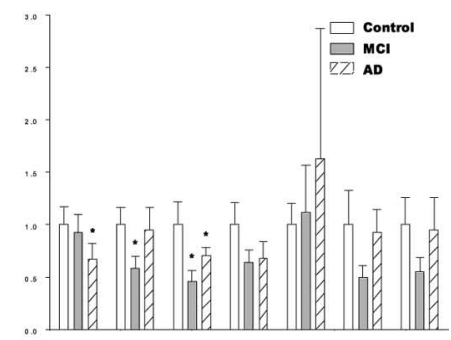

D

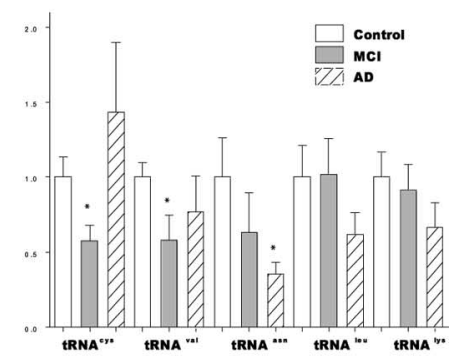

$\mathbf{F}$

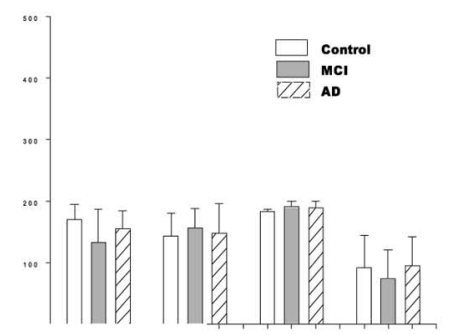

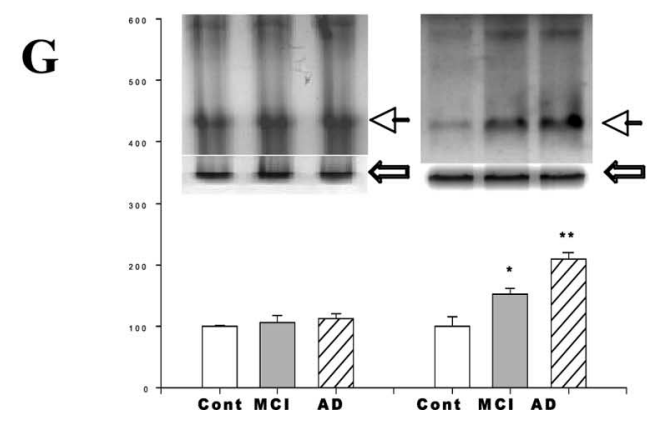

Figure 2. Alterations in rRNA and tRNA molecules, and elevated RNA oxidation, is observed in MCl and AD. $A, B$, The levels of individual rRNA species (45S, 35S, 285, 185, 5.85, 5S, and pre-5S) were analyzed by reverse transcription-PCR in the cerebellum $(\boldsymbol{A})$ and inferior parietal lobule $(\boldsymbol{B})$. Analysis was conducted in control, $\mathrm{MCl}$, and $\mathrm{AD}$ subjects. The levels of individual tRNA species were also calculated in the cerebellum $(\boldsymbol{C})$ and inferior parietal lobule $(\boldsymbol{D})$ of these same subjects. The expression of several initiation factors and their regulators (FRAP, phosphorylated p7056 kinase, PKR, and elF2) were analyzed in the cerebellum (E) and inferior parietal lobule $(\boldsymbol{F})$ of these same subjects. $\boldsymbol{G}$, An antibody against 8-OHG was used to detect oxidized RNA in total RNA pool from the cerebellum or inferior parietal lobule of control, $\mathrm{MCl}$, and $\mathrm{AD}$ subjects. The inserted photo is a representative result for control (Cont), $\mathrm{MCl}$, and early $\mathrm{AD}$ (from left to right). The dark arrow indicates oxidized RNA at the 285 rRNA position, with the white arrow representing the $18 \mathrm{~S}$ rRNA bands in the gel before transfer. Error bars represent SEM. ${ }^{*} p<0.01$ compared with control.

sis inhibitors is associated with ubiquitin depletion and/or decreased proteasome function (Hanna et al., 2003). Studies from our laboratory have recently demonstrated the ability of low-level proteasome inhibition to promote rRNA oxidation and alter RNA processing in neurons and glia (Ding et al., 2004). These data raise the real possibility of potential cross talk between the protein synthesis and protein degradation machinery in the brain, with impairments in protein synthesis potentially promoting deleterious alterations in protein degradation and/or impairments in protein degradation negatively influencing protein synthesis. 
Our findings are consistent with dramatic impairments in protein expression and profound shifts in steady-state kinetics for protein expression, occurring early in AD. These data will have profound, and as yet to be determined, influence on interpreting the numerous studies involving the analysis of proteomics and proteolysis in $\mathrm{AD}$ brain. Increasing our understanding of the effects of impaired protein synthesis on protein degradation and neurotoxicity in the brain is a central issue to be clarified in future studies. Studies are currently underway to determine which cell types are responsible for the decreased polyribosome function observed in the present study and to elucidate whether decreased polyribosome function may preferentially occurs within the synapse during the development of $\mathrm{AD}$.

\section{References}

Aloni R, Peleg D, Meyuhas O (1992) Selective translational control and nonspecific posttranscriptional regulation of ribosomal protein gene expression during development and regeneration of rat liver. Mol Cell Biol 12:2203-2212.

An WL, Cowburn RF, Li L, Braak H, Alafuzoff I, Iqbal K, Iqbal IG, Winblad B, Pei JJ (2003) Up-regulation of phosphorylated/activated p70 S6 kinase and its relationship to neurofibrillary pathology in Alzheimer's disease. Am J Pathol 163:591-607.

Braak H, Braak E (1991) Neuropathological stageing of Alzheimer-related changes. Acta Neuropathol (Berl) 82:239-259.

Chang RC, Wong AK, Ng HK, Hugon J (2002) Phosphorylation of eukaryotic initiation factor-2alpha (eIF2alpha) is associated with neuronal degeneration in Alzheimer's disease. NeuroReport 13:2429-2432.

Cosgrove JW, Rapoport SI (1986) Preparation of a cell-free extract from rat brain which can initiate protein synthesis in vitro. Neurochem Res 11:1289-1301.

DeKosky ST (2003) Pathology and pathways of Alzheimer's disease with an update on new developments in treatment. J Am Geriatr Soc 51:S314-S320.

Ding Q, Lewis JJ, Strum KM, Dimayuga E, Bruce-Keller AJ, Dunn JC, Keller JN (2002) Polyglutamine expansion, protein aggregation, proteasome activity, and neural survival. J Biol Chem 277:13935-13942.

Ding Q, Dimayuga E, Markesbery WR, Keller JN (2004) Proteasome inhibition increases DNA and RNA oxidation in astrocyte and neuron cultures. J Neurochem 91:1211-1218.

Ferrer I (2002) Differential expression of phosphorylated translation initiation factor 2 alpha in Alzheimer's disease and Creutzfeldt-Jakob's disease. Neuropathol Appl Neurobiol 28:441-451.

Flicker C, Ferris SH, Reisberg B (1991) Mild cognitive impairment in the elderly: predictors of dementia. Neurology 41:1006-1009.

Fromont-Racine M, Senger B, Saveanu C, Fasiolo F (2003) Ribosome assembly in eukaryotes. Gene 313:17-42.

Granneman S, Baserga SJ (2004) Ribosome biogenesis: of knobs and RNA processing. Exp Cell Res 296:43-50.

Han JM, Kim JY, Kim S (2003) Molecular network and functional implications of macromolecular tRNA synthetase complex. Biochem Biophys Res Commun 303:985-993.
Hanna J, Leggett DS, Finley D (2003) Ubiquitin depletion as a key mediator of toxicity by translational inhibitors. Mol Cell Biol 23:9251-9261.

Honda K, Smith MA, Zhu X, Baus D, Merrick WC, Tartakoff AM, Hattier T, Harris PL, Siedlak SL, Fujioka H, Liu Q, Moreira PI, Miller FP, Nunomura A, Shimohama S, Perry G (2005) Ribosomal RNA in Alzheimer disease is oxidized by bound redox-active iron. J Biol Chem 280:20978-20986.

Keller JN, Schmitt FA, Scheff SW, Ding Q, Chen Q, Butterfield DA, Markesbery WR (2005) Evidence of increased oxidative damage in subjects with mild cognitive impairment. Neurology 64:1152-1156.

Langstrom NS, Anderson JP, Lindroos HG, Winblad B, Wallace WC (1989) Alzheimer's disease-associated reduction of polysomal mRNA translation. Mol Brain Res 5:259-269.

Li X, An WL, Alafuzoff I, Soininen H, Winblad B, Pei JJ (2004) Phosphorylated eukaryotic translation factor $4 \mathrm{E}$ is elevated in Alzheimer brain. NeuroReport 15:2237-2240.

Luis CA, Loewenstein DA, Acevedo A, Barker WW, Duara R (2003) Mild cognitive impairment: directions for future research. Neurology 61:438-444.

Morris JC, Storandt M, Miller JP, McKeel DW, Price JL, Rubin EH, Berg L (2001) Mild cognitive impairment represents early-stage Alzheimer disease. Arch Neurol 58:397-405.

Nunomura A, Perry G, Pappolla MA, Wade R, Hirai K, Chiba S, Smith MA (1999) RNA oxidation is a prominent feature of vulnerable neurons in Alzheimer's disease. J Neurosci 19:1959-1964.

Onuki R, Bando Y, Suyama E, Katayama T, Kawasaki H, Baba T, Tohyama M, Taira K (2004) An RNA-dependent protein kinase is involved in tunicamycin-induced apoptosis and Alzheimer's disease. EMBO J 23:959-968.

Peel AL, Bredesen DE (2003) Activation of the cell stress kinase PKR in Alzheimer's disease and human amyloid precursor protein transgenic mice. Neurobiol Dis 14:52-62.

Petersen RC, Smith GE, Waring SC, Ivnik RJ, Kokmen E, Tangelos EG (1997) Aging, memory, and mild cognitive impairment. Int Psychogeriatr 9 [Suppl 1]:65-69.

Petersen RC, Smith GE, Waring SC, Ivnik RJ, Tangalos EG, Kokmen E (1999) Mild cognitive impairment: clinical characterization and outcome. Arch Neurol 56:303-308.

Riley KP, Snowden DA, Markesbery WR (2002) Alzheimer's neurofibrillary pathology and the spectrum of cognitive function: findings from the nun study. Ann Neurol 51:567-577.

Sajdel-Sulkowska EM, Marotta CA (1984) Alzheimer's disease brain: alterations in RNA levels and in a ribonuclease-inhibitor complex. Science 225:947-949.

Seshadri S, Wolf PA, Beiser A, Au R, McNulty K, White R, D'Agostino RB (1997) Lifetime risk of dementia and Alzheimer's disease. The impact of mortality on risk estimates in the Framingham Study. Neurology 49:1498-1504.

Tschochner H, Hurt E (2003) Pre-ribosomes on the road from the nucleolus to the cytoplasm. Trends Cell Biol 13:255-263.

Wang Y, Sekiguchi T, Noguchi E, Nishimoto T (2004) A hamster temperature-sensitive alanyl-tRNA synthetase mutant causes degradation of cell-cycle related proteins and apoptosis. J Biochem (Tokyo) 135:7-16.

Yang DC (1996) Mammalian aminoacyl-tRNA synthetases. Curr Top Cell Regul 34:101-136. 